\title{
Proteome alteration induced by hTERT transfection of human fibroblast cellsk
}

\author{
Gabriel D Mazzucchelli*1, Valérie Gabelica1, Nicolas Smargiasso', \\ Maximilien Fléron1, Wilson Ashimwe1, Frédéric Rosu1 ${ }^{1}$, Marie-Claire De \\ Pauw-Gillet ${ }^{2}$, Jean-François Riou ${ }^{3}$ and Edwin De Pauw ${ }^{1}$
}

Address: ${ }^{1}$ Laboratory of Mass Spectrometry; CART, GIGA, University of Liège, BAT. B6C, allée de la Chimie, 3, 4000 Liège 1, Belgium, ${ }^{2}$ Histology and Cytology Laboratory, GIGA, University of Liège, BAT. B6C, allée de la Chimie, 3, 4000 Liège 1, Belgium and ${ }^{3}$ Regulation et Dynamique des Genomes, Museum National d'Histoire Naturelle, USM 503, INSERM U565, CNRS UMR 5153, Paris, France

Email: Gabriel D Mazzucchelli* - gabriel.mazzucchelli@ulg.ac.be; Valérie Gabelica - v.gabelica@ulg.ac.be;

Nicolas Smargiasso - nsmargiasso@ulg.ac.be; Maximilien Fléron - m.fleron@ulg.ac.be; Wilson Ashimwe -wilson203be@yahoo.fr;

Frédéric Rosu - f.rosu@ulg.ac.be; Marie-Claire De Pauw-Gillet - marie-claire.depauw@ulg.ac.be; Jean-François Riou - riou@mnhn.fr; Edwin De Pauw - e.depauw@ulg.ac.be

* Corresponding author

Published: 17 April 2008

Proteome Science 2008, 6:12 doi:10.1186/1477-5956-6-12
Received: 30 November 2007

Accepted: 17 April 2008

This article is available from: http://www.proteomesci.com/content/6/I/12

(c) 2008 Mazzucchelli et al; licensee BioMed Central Ltd.

This is an Open Access article distributed under the terms of the Creative Commons Attribution License (http://creativecommons.org/licenses/by/2.0), which permits unrestricted use, distribution, and reproduction in any medium, provided the original work is properly cited.

\begin{abstract}
Background: Telomerase confers cellular immortality by elongating telomeres, thereby circumventing the Hayflick limit. Extended-life-span cells have been generated by transfection with the human telomerase reverse transcriptase (hTERT) gene. hTERT transfected cell lines may be of outstanding interest to monitor the effect of drugs targeting the telomerase activity. The incidence of hTERT gene transfection at the proteome level is a prerequisite to that purpose. The effect of the transfection has been studied on the proteome of human fibroblast (WI38). Cytosolic and nuclear fractions of WI38 cells, empty vector transfected WI38 (WI38-HPV) and hTERT WI38 cells were submitted to a 2DDIGE (Two-Dimensional Differential In-Gel Electrophoresis) analysis. Only spots that had a similar abundance in WI38 and WI38-HPV, but were differentially expressed in WI38 hTERT were selected for MS identification. This method directly points to the proteins linked with the hTERT expression. Number of false positive differentially expressed proteins has been excluded by using control WI38-HPV cells. The proteome alteration induced by hTERT WI38 transfection should be taken into account in subsequent use of the cell line for anti-telomerase drugs evaluation.
\end{abstract}

Results: 2D-DIGE experiment shows that 57 spots out of 2246 are significantly differentially expressed in the cytosolic fraction due to hTERT transfection, and 38 were confidently identified. In the nuclear fraction, 44 spots out of 2172 were selected in the differential proteome analysis, and 14 were identified. The results show that, in addition to elongating telomeres, hTERT gene transfection has other physiological roles, among which an enhanced ER capacity and a potent cell protection against apoptosis.

Conclusion: We show that the methodology reduces the complexity of the proteome analysis and highlights proteins implicated in other processes than telomere elongation. hTERT induced proteome changes suggest that telomerase expression enhances natural cell repair mechanisms and stress resistance probably required for long term resistance of immortalized cells. Thus, hTERT transfected cells can not be only consider as an immortal equivalent to parental cells but also as cells which are over-resistant to stresses. These findings are the prerequisite for any larger proteomics aiming to evaluate anti-telomerase drugs proteome alteration and thus therapeutics induced cell reactions. 


\section{Background}

Telomeres are specialized functional DNA-protein complexes that cap the end of linear chromosomes. Their role is to protect chromosomes from degradation, recombination, or fusion, and to prevent the chromosome ends from being detected as strand breaks. At each cell division, telomeres shorten until they reach a critical size that drives eukaryotic cells into replicative senescence. Telomere length therefore acts as a biological life clock. Telomerase, a ribonucleoprotein complex, is involved in telomere length maintenance in eukaryotic cells by adding telomeric repeats to the $3^{\prime}$ end of chromosomes. Telomerase activity is downregulated in most human cells during embryogenesis, thereby limiting their proliferative capacity. However, the reactivation of telomerase activity is observed in $90 \%$ of all human tumor cells, making this enzyme an attractive target for selective cancer therapy.

Reconstitution of telomerase activity by ectopic expression of the catalytic telomerase subunit (hTERT) cDNA stabilizes the telomere length of fibroblasts and other cell types that therefore acquire immortality [1]. Such hTERTtransfected cells have been proposed as immortal versions of normal human cells model with the advantage of indefinite proliferation. This strategy is applied for biochemical and physiological studies of normal cell growth, differentiation, genetic manipulation, etc [1-4]. More recently, experiments using transplanted telomerase-immortalized cells have been conducted in immunodeficient mice [5]. Adenocortical hTERT immortalized cells were able to replace cells with deficient functions. However such cellbased therapies raise important interrogations about medium and long term incidence of hTERT-immortalized cell autotransplantation cells. Indeed, several studies have evidenced that hTERT has other physiological roles beyond maintaining telomere such as potent incidence on malignant transformation of human fibroblasts by a telomere length-independent mechanisms [6-8]. Furthermore, the key role of telomerase in cancer cell immortalization led to the development of therapeutic strategies based on telomerase inhibition. A detailed characterization of hTERT-related transfection processes is therefore of outstanding interest to monitor anti-telomerase drug therapy.

We have studied here the sub-proteome modifications induced by hTERT transfection in the normal human fibroblast WI38 cell line. Cytoplasmic and nuclear fractions were analyzed by 2D DIGE. Comparison with controls, WI38 transfected with the empty vector (HPV) or parental untransfected WI38 cells has revealed the altered expression of proteins involved in apoptosis, cell cycle and endoplasmic reticulum homeostasis. The subfractionation method used allows telomerase detection by western blots, TRAP assay (Telomere repeat amplification protocol) experiment and reproducible extraction and isolation of the cytosolic and nuclear sub-proteomes, the latter one being enriched in low abundant proteins such as transcription factors and telomeric proteins. The interest of this work is to characterize the effect of hTERT expression at the proteome level of WI 38 cells for further investigating the effect of anti-telomerase drugs therapies in an integrated proteomic study.

\section{Results and Discussion}

To characterize the protein expression changes resulting from hTERT transfection, we performed a differential proteomic analysis in order to compare wild type WI 38 cells (WI38), hTERT transfected WI 38 cells (WI38-hTERT) and control HPV transfected WI 38 cells (WI38-HPV) harvested at the same number of population doublings $(\mathrm{PDL})$ after transfection and FACS sorting $(\mathrm{PDL}=10)$. The use of this relatively low passage number in vitro maintains in hTERT transfected cells normal cell characters, such as the capacity of contact inhibition and the karyotype [9]. It has been shown that hTERT expression protects the WI38 transfected cells from stress-induced apoptosis and necrosis [10]. Prolonged culturing of WI38-hTERT cells leads to a loss of density-dependent growth inhibition and to an onset of contact-induced, p53 dependent cell death [11]. Our cell lines presented density-dependent growth inhibition. For the proteomics analysis, our three cell lines were maintained at $90 \%$ confluence, and in exponential growth phase. In these conditions, the population doubling levels were similar.

2D DIGE was performed on both nuclear and cytosolic cell fractions. The subfractionation method used relies on a complementary and very different 2D gel images (Figure 1) which is necessary for low abundant nuclear proteins differential analysis. Nuclear fraction corresponds to $5.89 \% \pm 0.41$ (mean value over 6 independent experiments) of the total protein content. Protein spots that showed either an increase or a decrease in intensity superior to $30 \%$, together with a statistically significant Student's $t$-test $(p<0.05)$ were considered as being differentially expressed. Interestingly, numbers (Table 1) of differentially expressed proteins were found between parental cells and control HPV WI 38 cells. These modifications are thus a consequence of the general transfection and are not due to hTERT gene transfection. In this study only proteins which are differentially expressed between parental cells and hTERT cells and have in addition the same expression in parental cell and control HPV WI 38 cells were selected for the study and submitted to mass spectrometry based identification. In the cytosolic fraction, 57 spots out of 2246 are significantly differentially expressed (Table 1), and 38 were confidently identified (Table 2). In the nuclear fraction, 44 spots out of 2172 
Table I: 2D DIGE spots selection.

\begin{tabular}{|c|c|c|}
\hline & Nuclear fraction & Cytosolic fraction \\
\hline Total number of spots differentially expressed in WI38/WI38-hTERT & 190 & 210 \\
\hline Number of spots differentially expressed due to transfection (WI38/WI38-HPV) & 146 & 153 \\
\hline $\begin{array}{l}\text { By difference, number of spots differentially expressed due only to hTERT overexpression (number of } \\
\text { identified spots are in parentheses) }\end{array}$ & $44(14)$ & $57(38)$ \\
\hline
\end{tabular}

Number of spots differentially expressed in 2D-DIGE experiment (Student's t-test $p<0.05$ and increase or decrease intensity superior at 30\%). Selection based on spots differentially expressed in WI38/hTERT WI 38, but similarly expressed in WI38 and control WI38-HPV.

were selected in the differential proteome analysis (Table 1 ), and 14 were identified (Table 3 ).

\section{Functional protein association network of the proteins differentially expressed due to hTERT transfection [ 12]} Based on STRING protein-protein interactions predictions an association network of the proteins which have their expression modified due to hTERT transfection was created (Figure 2). The Table 4 describes the 15 proteins that were automatically selected by STRING to enlarge the protein association network of the Figure 2. This bioinformatics analysis evidenced protein groups which have their expression modified due to hTERT transfection in which proteins involved in ubiquitin-proteasome protein degradation pathway, nuclear-cytosol transport, endoplasmic reticulum functions, pre-mRNAs processing and cell several chaperone functions. This network will be further compared to those of anti telomerase drugs experiments.

\section{$U_{p}$ regulation of the heat shock protein 90-alpha}

The heat shock protein 90-alpha (hsp90 $\alpha$ ) is upregulated by a factor 1.42 in the nuclear fraction of hTERT WI38 cells. Hsp90 $\alpha$ exerts its chaperon function to ensure the correct conformation, activity, intracellular localization and proteolytic turnover of a range of proteins that are involved in cell growth, differentiation and survival [13]. More specifically, hsp90 $\alpha$ interacts with telomerase complex and occupy a central place in our protein association network (Figure 2). Hsp90 $\alpha$ is involved in allowing RNA template of the telomerase (hTR) to bind hTERT and also in fine tuning and stabilizing the structure of the telomerase complex $[14,15]$. Its central role in the telomerase activity modulation and in multiple signaling pathways and biological processes makes it a relevant target for anti cancer therapy. Number of study are currently evaluating clinical activity of hsp90 inhibitors in cancer therapeutics [16-22]. Our DIGE study links the overexpression of the hsp90 $\alpha$ with the ectopic expression of hTERT and suggests a key role of this chaperone in the subsequent cell adaptation to immortalization. In addition, Hiyama and coworkers have shown in a differential gene expression profiles study that the hsp $90 \alpha$ is overexpressed in tumor with high telomerase activity comparing tumor with low telomerase activity [23]. Theses findings emphasize the interest of anti hsp90 targeting drugs therapy and shows the interest of such proteomics methodology for potential biomarkers discovery and further drugs candidates characterization and preclinical validation.

\section{Down-regulation of apoptotic effectors Galectin-I and Annexin 5}

Galectin-1 (Gal-1) is downregulated by a factor of 2.1 in the nuclear proteome of hTERT-transfected cells. Gal-1 is a highly conserved protein with a carbohydrate-recognition domain that binds beta-galactoside. Recently Gal-1 was shown to be implicated in cell growth, apoptosis and cell differentiation and survival of effector T cells [24-27]. Exogenously added recombinant Gal-1 induces apoptosis by the mitochondrial and death receptor pathways of MA10 tumor Leydig cells. In contrast, low concentrations of Gal-1 significantly promote cell proliferation, without inducing cell death [26]. Walzel and al. have shown that Gal-1 triggers through binding to N-linked glycans a $\mathrm{Ca}^{2+-}$ sensitive apoptotic pathway [28].

Annexin 5 is downregulated by a factor of 2.64 in the cytosolic proteome of hTERT-transfected cells. Annexins are abundant $\mathrm{Ca}^{2+-}$ dependant phospholipids-binding proteins. Depletion of endogenous annexin 5 with siRNA inhibits delta protein kinase $\mathrm{C}$ functions in which cellular processes such as growth, differentiation and apoptosis $[29,30]$. In addition Hawkins and co-workers have proven that annexin 5 lack expression results in reduced susceptibility to a range of apoptotic stimuli, and that annexin 5 (-/-) cells are more resistant to apoptosis [31].

The downregulation of these two proteins in hTERT-transfected cells suggests that telomerase expression, in addition to its immortalization effect, induces a protection against apoptosis, compared to WI 38 cells. In agreement, modulation of apoptosis have been reported [32-34].

\section{Upregulation of Cajal bodies associated factors}

Cleavage stimulator factor $50 \mathrm{kDa}$ subunit (CstF-50) is upregulated by a factor of 1.57 (T-test: 1.5E-03), and cleavage and polyadenylation specificity factor 5 (CPSF$25)$ by a factor of 1.35 (T-test: 1.6E-02) in the nuclear proteome of hTERT transfected cells. CstF-50 is a subunit of 
Table 2: Cytosolic differentially expressed proteins identification and regulation

\begin{tabular}{|c|c|c|c|c|c|c|c|c|}
\hline \multirow[b]{2}{*}{ Swiss-Prot AC } & \multirow[b]{2}{*}{$\begin{array}{l}\text { Gene name, } \\
\text { STRING protein } \\
\text { association } \\
\text { network legend }\end{array}$} & \multirow[b]{2}{*}{ Protein name } & \multirow[b]{2}{*}{ Function } & \multicolumn{2}{|c|}{ hTERTt-WI38/WI38 } & \multicolumn{2}{|c|}{ hTERT-WI38/HPV-WI38 } & \multirow[t]{2}{*}{ Reference } \\
\hline & & & & T-test & Regulation & T-test & Regulation & \\
\hline [O43852] & CALR & Calumenin precursor & $\begin{array}{l}\mathrm{Ca}(2+) \text {-binding, secretory } \\
\text { pathway }\end{array}$ & I.0E-03 & 2.27 & $1.6 \mathrm{E}-02$ & 1.5 & {$[40]$} \\
\hline [QI5293] & $\mathrm{RCNI}$ & Reticulocalbin-I precursor & $\begin{array}{l}\mathrm{Ca}(2+) \text {-binding, secretory } \\
\text { pathway }\end{array}$ & I.3E-04 & 2.11 & $4.2 \mathrm{E}-04$ & 1.85 & {$[40]$} \\
\hline$[\mathrm{PI} 4625]$ & HSP90BI & $\begin{array}{l}\text { Endoplasmin precursor } \\
\text { (GRP94) }\end{array}$ & $\begin{array}{l}\text { ER chaperone, } \mathrm{Ca}(2+) \\
\text { binding, anti-apoptosis }\end{array}$ & I.4E-05 & 2.1 & I.6E-03 & 1.26 & {$[47,59]$} \\
\hline [Q|4697] & GANAB & $\begin{array}{l}\text { Neutral alpha-glucosidase } \\
A B \text { precursor }\end{array}$ & $\begin{array}{l}\text { Protein O-glucosyl } \\
\text { hydrolase }\end{array}$ & 4.9E-08 & 2.06 & $5.5 \mathrm{E}-06$ & 1.42 & \\
\hline [O95302] & FKBP9L & $\begin{array}{l}\text { FK506-binding protein } 9 \\
\text { precursor (FKBP9) }\end{array}$ & $\begin{array}{l}\text { Peptidyp propyl isomerase } \\
\text { (PPI), accelerate protein } \\
\text { folding }\end{array}$ & $9.9 \mathrm{E}-05$ & 2.04 & $3.9 \mathrm{E}-03$ & 1.41 & {$[52]$} \\
\hline [Q9Y4LI] & HYOUI & $\begin{array}{l}\text { I50 kDa oxygen-regulated } \\
\text { protein precursor } \\
\text { (ORPI50) }\end{array}$ & $\begin{array}{l}\text { ER chaperone, exchange } \\
\text { factor for GRP78 }\end{array}$ & I.2E-03 & 1.98 & $2.3 \mathrm{E}-03$ & 1.8 & {$[47,60]$} \\
\hline [Q9BS26] & TXNDC4 & $\begin{array}{l}\text { Thioredoxin domain- } \\
\text { containing protein } 4 \\
\text { precursor (ERp44) }\end{array}$ & $\begin{array}{l}\text { Control of oxidating } \\
\text { protein folding, EROIL } \\
\text { partner }\end{array}$ & $3.5 \mathrm{E}_{-} 06$ & 1.89 & $7.2 \mathrm{E}_{-} 05$ & 1.57 & {$[6 \mathrm{I}, 62]$} \\
\hline [O43852] & CALU & Calumenin precursor & $\begin{array}{l}\mathrm{Ca}(2+) \text {-binding, secretory } \\
\text { pathway }\end{array}$ & $\mathrm{I} .80 \mathrm{E}-05$ & 1.80 & 3.7E-03 & 1.35 & {$[40]$} \\
\hline [QI5293] & $\mathrm{RCNI}$ & Reticulocalbin-I precursor & $\begin{array}{l}\mathrm{Ca}(2+) \text {-binding, secretory } \\
\text { pathway }\end{array}$ & $2.5 \mathrm{E}-02$ & 1.78 & $6.2 \mathrm{E}-02$ & 1.51 & {$[40]$} \\
\hline [075131] & CPNE3 & Copine-3 & $\begin{array}{l}\mathrm{Ca}(2+) \text {-dependent } \\
\text { phospholipid-binding } \\
\text { proteins }\end{array}$ & 7.4E-04 & 1.73 & $1.2 \mathrm{E}-03$ & 1.59 & {$[63,64]$} \\
\hline [Q8NBS9] & TXNDC5 & $\begin{array}{l}\text { Thioredoxin domain- } \\
\text { containing protein } 5 \\
\text { precursor (Erp } 46 \text { ) }\end{array}$ & Thiol oxydoreductase & $3.2 \mathrm{E}-03$ & 1.73 & $4.9 \mathrm{E}-03$ & 1.65 & {$[62,65]$} \\
\hline$[P|| 02 I]$ & HSPA5 & $\begin{array}{l}78 \text { kDa glucose-regulated } \\
\text { protein precursor (GRP78) }\end{array}$ & $\begin{array}{l}\text { ER chaperone, } \mathrm{Ca}(2+)- \\
\text { binding, ER stress sensor, } \\
\text { anti-apoptosis }\end{array}$ & $1.5 \mathrm{E}-02$ & 1.65 & 7.4E-03 & 1.57 & {$[47,66]$} \\
\hline [PI3674] & P4HAI & $\begin{array}{l}\text { Prolyl 4-hydroxylase alpha- } \\
\text { I subunit precursor }\end{array}$ & $\begin{array}{l}\text { Hypoxia-inducible collagen } \\
\text { synthesis }\end{array}$ & $2.0 \mathrm{E}-08$ & 1.65 & $1.3 \mathrm{E}-06$ & 1.77 & {$[67]$} \\
\hline [OI5460] & P4HA2 & $\begin{array}{l}\text { Prolyl 4-hydroxylase alpha- } \\
2 \text { subunit precursor }\end{array}$ & $\begin{array}{l}\text { Hypoxia-inducible collagen } \\
\text { synthesis }\end{array}$ & $2.8 \mathrm{E}-04$ & 1.64 & $1.5 \mathrm{E}-03$ & 1.43 & {$[67]$} \\
\hline [P07237] & $\mathrm{P} 4 \mathrm{HB}$ & $\begin{array}{l}\text { Protein disulfide-isomerase } \\
\text { precursor }\end{array}$ & $\begin{array}{l}\text { Rearrangement of -S-S- } \\
\text { bonds in proteins }\end{array}$ & $2.0 \mathrm{E}-06$ & 1.64 & 2. IE-04 & 1.28 & {$[68]$} \\
\hline [Q9H2D6] & TRIOBP & $\begin{array}{l}\text { TRIO and F-actin-binding } \\
\text { protein }\end{array}$ & $\begin{array}{l}\text { May regulate actin } \\
\text { cytoskeletal organization }\end{array}$ & $8.0 \mathrm{E}-05$ & 1.59 & $4.9 \mathrm{E}-03$ & 1.35 & \\
\hline [P30I0I] & GRP58 & $\begin{array}{l}\text { Protein disulfide-isomerase } \\
\text { A3 precursor (PDI-A3) }\end{array}$ & $\begin{array}{l}\text { Rearrangement of -S-S- } \\
\text { bonds in proteins }\end{array}$ & $8.6 \mathrm{E}-07$ & 1.57 & $2.8 \mathrm{E}-06$ & 1.48 & {$[68]$} \\
\hline [Q96HE7] & EROIL & $\begin{array}{l}\text { EROI-like protein alpha } \\
\text { precursor (EROIL) }\end{array}$ & $\begin{array}{l}\text { Protein disulfide isomerases } \\
\text { oxydoreductase }\end{array}$ & $2.7 \mathrm{E}-02$ & 1.54 & 4.7E-02 & 1.44 & {$[61,69]$} \\
\hline [P27797] & CALR & Calreticulin precursor & $\begin{array}{l}\text { ER chaperone, } \mathrm{Ca}(2+) \text { - } \\
\text { binding, glycoprotein } \\
\text { folding }\end{array}$ & $2.9 \mathrm{E}-02$ & 1.46 & $7.8 \mathrm{E}-03$ & 1.61 & {$[47]$} \\
\hline [QI5084] & PDIA6 & $\begin{array}{l}\text { Protein disulfide-isomerase } \\
\text { A6 precursor (PDI-A6) }\end{array}$ & $\begin{array}{l}\text { Rearrangement of -S-S- } \\
\text { bonds in proteins }\end{array}$ & $8.8 \mathrm{E}-05$ & 1.45 & I.IE-04 & 1.31 & [68] \\
\hline [Q99439] & CNN2 & Calponin-2 & $\begin{array}{l}\mathrm{Ca}(2+) \text {-binding, actin- } \\
\text { binding RNA helicase which }\end{array}$ & 2.IE-04 & 1.33 & 2.7E-03 & 1.25 & {$[70,7 I]$} \\
\hline [P60842] & EIF4AI & $\begin{array}{l}\text { Eukaryotic initiation factor } \\
4 A-I\end{array}$ & $\begin{array}{l}\text { mediates binding of mRNA } \\
\text { to the ribosome }\end{array}$ & $6.6 \mathrm{E}-05$ & 1.33 & $8.6 \mathrm{E}-05$ & 1.48 & \\
\hline [P30I0I] & GRP58 & $\begin{array}{l}\text { Protein disulfide-isomerase } \\
\text { A3 precursor (PDI-A3) }\end{array}$ & $\begin{array}{l}\text { Rearrangement of -S-S- } \\
\text { bonds in proteins }\end{array}$ & $3.9 \mathrm{E}-03$ & 1.29 & $2.0 \mathrm{E}-03$ & 1.44 & {$[68]$} \\
\hline [P27797] & CALR & Calreticulin precursor & $\begin{array}{l}\text { ER chaperone, } \mathrm{Ca}(2+)- \\
\text { binding, glycoprotein } \\
\text { folding }\end{array}$ & 0.18 & 1.26 & $2.6 \mathrm{E}-02$ & 1.68 & {$[47]$} \\
\hline [P5I665] & PSMD7 & $\begin{array}{l}\text { 26S proteasome non- } \\
\text { ATPase regulatory subunit } \\
7\end{array}$ & $\begin{array}{l}\text { Regulation of ubiquitinated } \\
\text { proteins degradation }\end{array}$ & $2.2 \mathrm{E}-02$ & 0.76 & I.4E-02 & 0.71 & \\
\hline [P04406] & HSD35 & $\begin{array}{l}\text { Glyceraldehyde-3- } \\
\text { phosphate dehydrogenase }\end{array}$ & Glycolytic pathway & I.IE-02 & 0.75 & 7.7E-04 & 0.70 & \\
\hline [Q99426] & CKAPI & $\begin{array}{l}\text { Tubulin-specific chaperone } \\
\text { B }\end{array}$ & $\begin{array}{l}\text { Chaperone, tubulin } \\
\text { organisation }\end{array}$ & I.3E-03 & 0.75 & $8.8 \mathrm{E}-04$ & 0.72 & \\
\hline [P04406] & HSD35 & $\begin{array}{l}\text { Glyceraldehyde-3- } \\
\text { phosphate dehydrogenase }\end{array}$ & Glycolytic pathway & $4.9 \mathrm{E}-03$ & 0.74 & $9.4 \mathrm{E}-03$ & 0.76 & \\
\hline [P0921I] & GSTPI & Glutathione S-transferase P & Oxidative stress & 6.IE-03 & 0.72 & 4.7E-02 & 0.81 & \\
\hline [P04075] & ALDOA & $\begin{array}{l}\text { Fructose-bisphosphate } \\
\text { aldolase A }\end{array}$ & Glycolytic pathway & $6.4 \mathrm{E}-03$ & 0.71 & $7.2 \mathrm{E}-02$ & 0.85 & \\
\hline [P04075] & ALDOA & $\begin{array}{l}\text { Fructose-bisphosphate } \\
\text { aldolase A }\end{array}$ & Glycolytic pathway & $8.2 \mathrm{E}-04$ & 0.69 & 4.7E-02 & 0.75 & \\
\hline [P04406] & HSD35 & $\begin{array}{l}\text { Glyceraldehyde-3- } \\
\text { phosphate dehydrogenase }\end{array}$ & Glycolytic pathway & I.2E-03 & 0.61 & $1.3 \mathrm{E}-03$ & 0.69 & \\
\hline
\end{tabular}


Table 2: Cytosolic differentially expressed proteins identification and regulation (Continued)

\begin{tabular}{|c|c|c|c|c|c|c|c|}
\hline [P04792] & HSPBI & $\begin{array}{l}\text { Heat-shock protein beta-I } \\
\text { (HSP27) }\end{array}$ & $\begin{array}{l}\text { Chaperone, actin } \\
\text { organization }\end{array}$ & $3.8 \mathrm{E}-03$ & 0.61 & $3.4 \mathrm{E}-03$ & 0.65 \\
\hline [P05 I20] & SERPINB2 & $\begin{array}{l}\text { Plasminogen activator } \\
\text { inhibitor } 2 \text { precursor }\end{array}$ & $\begin{array}{l}\text { Plasminogen activator } \\
\text { inhibitor }\end{array}$ & $3.3 \mathrm{E}-04$ & 0.56 & $1.3 \mathrm{E}-03$ & 0.59 \\
\hline [PI7987] & TCPI & $\begin{array}{l}\text { T-complex protein I } \\
\text { subunit alpha }\end{array}$ & $\begin{array}{l}\text { Chaperone, protein folding, } \\
\text { actin and tubulin folding }\end{array}$ & $1.7 \mathrm{E}-02$ & 0.56 & 3.7E-03 & 0.67 \\
\hline [P08758] & ANXA5 & Annexin A5 & $\begin{array}{l}\mathrm{Ca}(2+) \text {-dependant } \\
\text { phospholipids-binding, } \\
\text { apoptosis regulation }\end{array}$ & 2.IE-04 & 0.39 & $2.6 \mathrm{E}-04$ & 0.40 \\
\hline [P07737] & PFNI & Profilin-I & $\begin{array}{l}\text { Intranuclear movements, } \\
\text { assembly of transcription } \\
\text { complexes }\end{array}$ & $3.3 \mathrm{E}-04$ & 0.38 & $1.0 \mathrm{E}-02$ & 0.33 \\
\hline [P07737] & PFNI & Profilin-I & $\begin{array}{l}\text { Intranuclear movements, } \\
\text { assembly of transcription } \\
\text { complexes }\end{array}$ & $3.2 \mathrm{E}-02$ & 0.37 & 2.7E-02 & 0.4 \\
\hline
\end{tabular}

List of the proteins differentially expressed due to hTERT transfection in the cytosolic fraction of human WI38 cells. Listed by decreasing regulation.

the heterotrimer CstF. CstF and CPSF-25 are required for polyadenylation and 3'-end cleavage of mammalian premRNAs. Schul and co-workers have shown that "cleavage bodies" (compact spherical fibrous structures containing CstF et CPSF factors) are intimately associated with Cajal bodies (CBs) [35]. hTERT and the telomerase RNA component, hTR, are also found in CBs. Ectopic expression of hTERT results in accumulation of hTR in CBs in primary fibroblasts or smooth muscle cells, but not in normal cells or in telomerase-negative (ALT) tumor cells [36]. It has been proposed that CBs could act as storage sites and deliver components of the telomerase complex when needed [37]. hTR localization in CBs is an important regulatory mechanism for telomere length homeostasis in human cells: mutant hTR failing to accumulate in CBs results in a functional deficiency and a decreasing association of telomerase with telomere [38]. The RNA component of human telomerase (hTR) includes H/ACA and CR7 domains required for 3' end processing, localization and accumulation. $3^{\prime}$ end processing is a prerequisite for

Table 3: Nuclear differentially expressed proteins identification and regulation

\begin{tabular}{|c|c|c|c|c|c|c|c|}
\hline \multirow[b]{2}{*}{ Swiss-Prot AC } & \multirow[b]{2}{*}{$\begin{array}{l}\text { Gene name, } \\
\text { STRING protein } \\
\text { association network } \\
\text { legend }\end{array}$} & \multirow[b]{2}{*}{ Protein name } & \multirow[b]{2}{*}{ Function } & \multicolumn{2}{|c|}{ hTERTt-WI38/WI38 } & \multicolumn{2}{|c|}{ hTERT-WI38/HPV-WI38 } \\
\hline & & & & T-test & Regulation & T-test & Regulation \\
\hline [P3।943] & HNRPHI & $\begin{array}{l}\text { Heterogeneous nuclear } \\
\text { ribonucleoprotein } \mathrm{H}\end{array}$ & Pre-mRNAs processing & 4.4E-03 & 1.73 & $3.0 \mathrm{E}-02$ & 1.58 \\
\hline [P08235] & $\mathrm{NR} 3 \mathrm{C} 2$ & Mineralocorticoid receptor & $\begin{array}{l}\text { Binds to mineralocorticoid response } \\
\text { elements (MRE) and transactivates } \\
\text { target genes }\end{array}$ & $6.1 \mathrm{E}-03$ & 1.65 & $1.6 \mathrm{E}-02$ & 1.53 \\
\hline [O|4579] & COPE & Coatomer subunit epsilon & Implicated in vesicles trafficking & $4.2 \mathrm{E}-02$ & 1.62 & 0.12 & 1.33 \\
\hline [Q05048] & CSTFI & $\begin{array}{l}\text { Cleavage stimulation factor } \\
50 \mathrm{kDa} \text { subunit }\end{array}$ & $\begin{array}{l}\text { Polyadenylation and } 3 \text { '-end cleavage of } \\
\text { mammalian pre-mRNAs }\end{array}$ & $1.5 \mathrm{E}-03$ & 1.57 & $5.6 \mathrm{E}-03$ & 1.64 \\
\hline [P07900] & HSPCA & $\begin{array}{l}\text { Heat shock protein HSP 90- } \\
\text { alpha }\end{array}$ & $\begin{array}{l}\text { Chaperone, } 680 \mathrm{kDa} \text { human } \\
\text { telomerase complex partner [72] }\end{array}$ & I.5E-02 & 1.42 & $2.2 \mathrm{E}-04$ & 2.05 \\
\hline [P62826] & ARA24 & $\begin{array}{l}\text { GTP-binding nuclear } \\
\text { protein Ran }\end{array}$ & nucleocytoplasmic transport & $2.0 \mathrm{E}-02$ & 1.37 & 6.7E-03 & 1.24 \\
\hline [O43809] & ENSP0000030 0291 & $\begin{array}{l}\text { Cleavage and } \\
\text { polyadenylation specificity } \\
\text { factor } 5\end{array}$ & $\begin{array}{l}\text { Polyadenylation and 3'-end cleavage of } \\
\text { mammalian pre-mRNAs }\end{array}$ & I.6E-02 & 1.35 & - & 1.35 \\
\hline [Q|3838] & ATP6VIG2 & $\begin{array}{l}\text { splicesome RNA helicase } \\
\text { BATI }\end{array}$ & $\begin{array}{l}\text { Splice factor, required for mRNA } \\
\text { export }\end{array}$ & $6.3 \mathrm{E}-03$ & 1.34 & $1.7 \mathrm{E}-03$ & 1.5 \\
\hline$[\mathrm{P} 25788]$ & PSMA3 & $\begin{array}{l}\text { Proteasome subunit alpha } \\
\text { type } 3\end{array}$ & Protein degradation & $5.6 \mathrm{E}-03$ & 0.68 & 4.7E-02 & 0.75 \\
\hline [P28072] & PSMB6 & $\begin{array}{l}\text { Proteasome subunit beta } \\
\text { type } 6 \text { precursor }\end{array}$ & Protein degradation & $3.8 \mathrm{E}-05$ & 0.65 & $3.0 \mathrm{E}-04$ & 0.66 \\
\hline [P08865] & RPSA & 40 S ribosomal protein SA & Protein synthesis & I.3E-04 & 0.58 & $5.4 \mathrm{E}-04$ & 0.60 \\
\hline [P60842] & EIF4AI & $\begin{array}{l}\text { Eukaryotic initiation factor } \\
4 \mathrm{~A}-\mathrm{I}\end{array}$ & $\begin{array}{l}\text { RNA helicase which mediates binding } \\
\text { of mRNA to the ribosome }\end{array}$ & 3.IE-02 & 0.54 & $1.2 \mathrm{E}-0 \mathrm{I}$ & 0.52 \\
\hline [P09382] & LGALSI & Galectin-I & $\begin{array}{l}\text { Cell growth, apoptosis and cell } \\
\text { differentiation }\end{array}$ & $8.8 \mathrm{E}-07$ & 0.50 & $1.2 \mathrm{E}-06$ & 0.51 \\
\hline [Q|2906] & ILF3 & $\begin{array}{l}\text { Interleukin enhancer- } \\
\text { binding factor } 3\end{array}$ & $\begin{array}{l}\text { Translation inhibitory protein of acid } \\
\text { beta-glucosidase and other mRNAs, } \\
\text { IL2 transcription regulator, promote } \\
\text { the formation of stable DNA- } \\
\text { dependent protein kinase holoenzyme } \\
\text { complexes on DNA }\end{array}$ & I.IE-05 & 0.47 & $9.5 \mathrm{E}-04$ & 0.66 \\
\hline
\end{tabular}




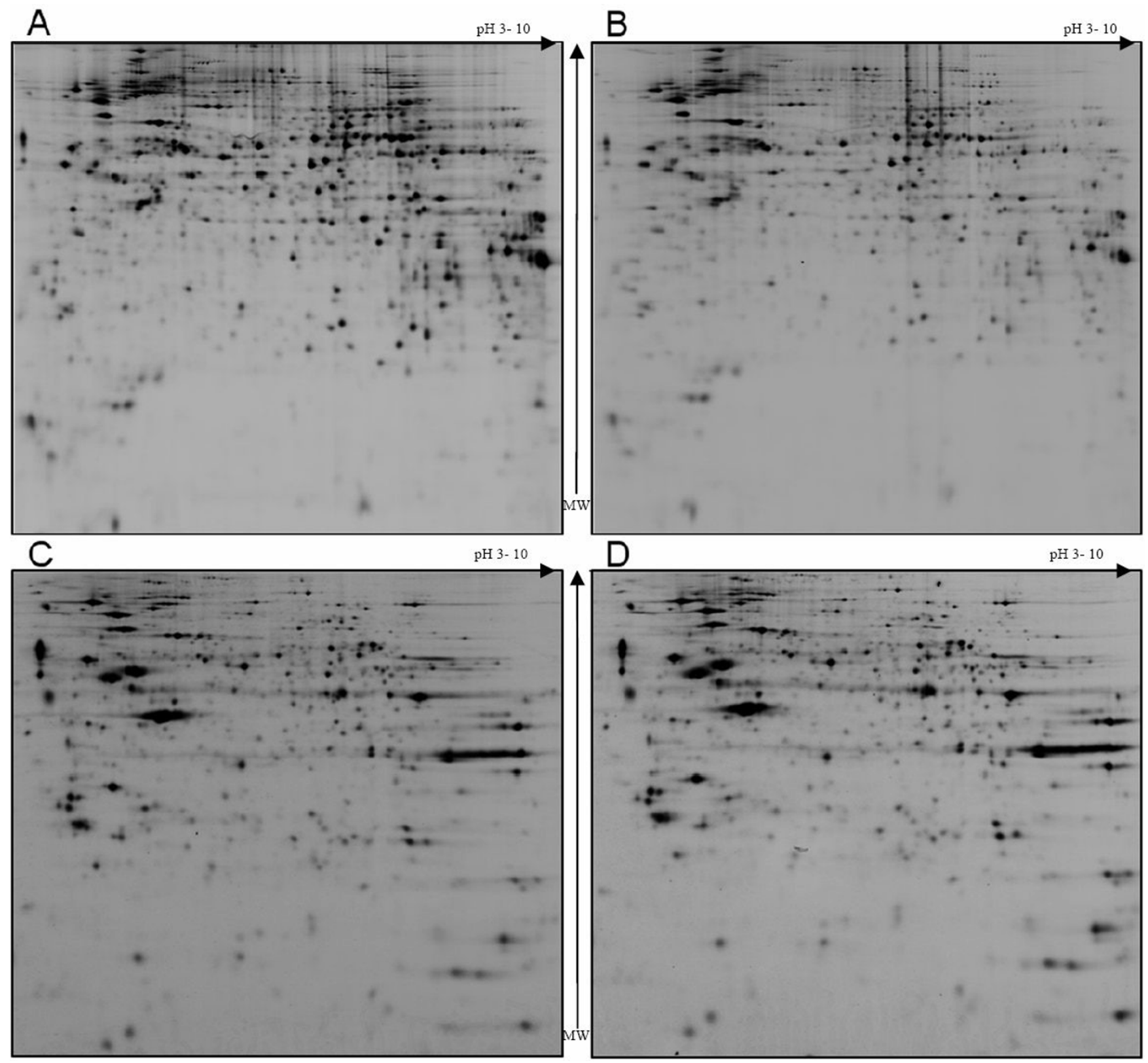

Figure I

Nuclear and cytosolic 2D DIGE gels. Two dimensional gel electrophoresis images of nuclear (A, B) and cytosolic fractions (C, D) of WI38 cells. The subfractionation method used allows reproducible extraction and isolation of the nuclear and cytosolic sub-proteomes.

translocation of hTR to CBs [38]. A probable role of CstF50 and CPSF-25 in hTR maturation may be an important regulation process and requires further investigations.

Profilin 1 is a known component of Cajal bodies supposed involved in both ATP-dependant intranuclear movements and in the assembly of transcription complexes [39]. Our results show that this protein is downregulated in cytosol hTERT transfected cells. Modulation of this protein may also implicate CBs functions in hTERTtransfected cells.

\section{Enhanced protective ER functions in hTERT transfected cells}

22 out of the 38 proteins identified in the cytosolic fraction are involved in endoplasmic reticulum functions and are up-regulated in the hTERT transfected cells. Our results are consistent with this recent report and underline the 


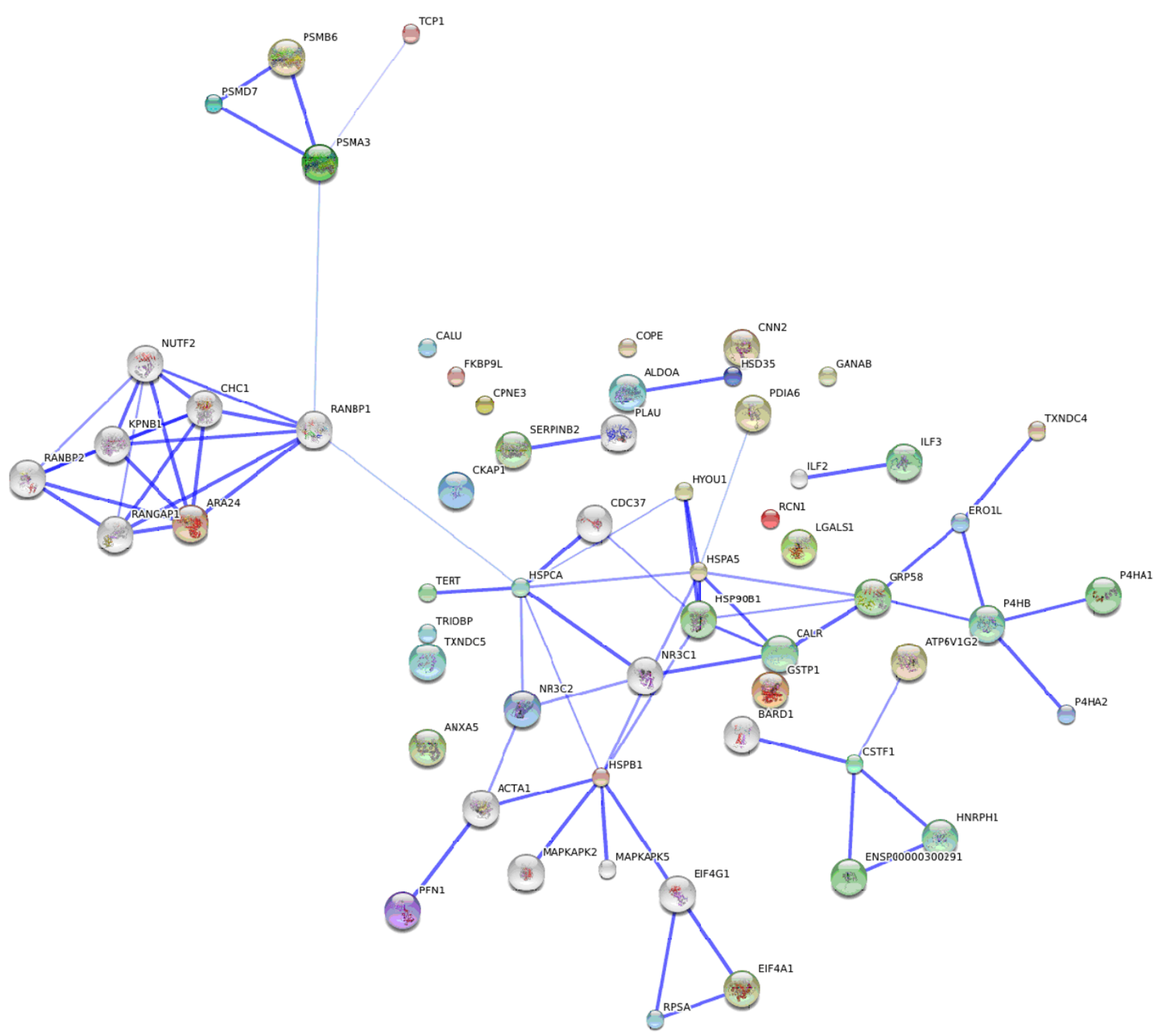

\section{Figure 2}

Protein association network of the proteins differentially expressed due to hTERT transfection. Protein-protein interactions predictions from the identified proteins which have their expression modified due to hTERT transfection. Based on STRING [12]. Network Display - Nodes are either coloured (differentially expressed proteins in this study except TERT that was manually introduced) or white (nodes of a higher iteration/depth). Additional white nodes are automatically generated by STRING to maximize existing interactions. Stronger associations are represented by thicker lines. Parameters used to create the protein association network: medium confidence and 15 additional (white) nodes. Protein descriptions of the coloured nodes are described in Table 2 and 3 those of white nodes in Table 4.

implication of the CERC protein family as an important signaling pathway in hTERT transfected cells. Reticulocalbin and calumenin belong to the CREC (Cab45, reticulocalbin, ERC-45, calumenin) proteins, which constitute a family of EF-hand (helix-turn-helix structural motif) calcium binding proteins localized to the secretory pathway
[40]. It has been proposed that CREC family is essential for cell survival because homozygous deletion of a region containing the reticulocalbin gene is lethal [41]. Several reports described their important role in pathophysiological processes especially in connection with malignant transformation [42-44]. Another recent study indicates 
Table 4: Protein descriptions of the white nodes of the Protein association network (Figure 2)

\begin{tabular}{ll}
\hline $\begin{array}{l}\text { Gene name, STRING protein association } \\
\text { network legend }\end{array}$ & Protein name \\
\hline ACTAI & \\
BARDI & Actin, alpha skeletal muscle (Alpha-actin-I) \\
CDC37 & BRCAI-associated RING domain protein I (BARD-I) \\
& Hsp90 co-chaperone Cdc37 (Hsp90 chaperone protein kinase-targeting subunit) \\
(p50Cdc37) & \\
CHCI & Regulator of chromosome condensation (Cell cycle regulatory protein) \\
EIF4GI & Eukaryotic translation initiation factor 4 gamma I (elF-4-gamma I) (elF-4GI) (elF-4G I) \\
& (p220) \\
ILF2 & Interleukin enhancer-binding factor 2 (Nuclear factor of activated T-cells 45 kDa) \\
KPNBI & Importin beta-I subunit (Karyopherin beta-I subunit) (Nuclear factor P97) (Importin 90) \\
MAPKAPK2 & MAP kinase-activated protein kinase 2 (EC 2.7.I.-) (MAPK-activated protein kinase 2) \\
& (MAPKAP kinase 2) (MAPKAPK-2) \\
MAPKAPK5 & MAP kinase-activated protein kinase 5 (EC 2.7.I.37) (MAPK-activated protein kinase 5) \\
& (MAPKAP kinase 5) (p38-regulated/activated protein kinase) \\
NR3CI & Glucocorticoid receptor (GR) \\
NUTF2 & Nuclear transport factor 2 (NTF-2) (Placental protein I5) (PPI5) \\
PLAU & Urokinase-type plasminogen activator precursor (EC 3.4.2I.73) (uPA) (U-plasminogen \\
& activator) [Contains: Urokinase-type plasminogen activator long chain A; Urokinase-type \\
plasminogen activator short chain A; Urokinase-type plasminogen activator chain B] & Ran-specific GTPase-activating protein (Ran binding protein I) (RanBPI) \\
RANBPI & Ran-binding protein 2 (RanBP2) (Nuclear pore complex protein Nup358) (Nucleoporin \\
RANBP2 & Nup358) (358 kDa nucleoporin) (P270) \\
RANGAPI & Ran GTPase-activating protein I
\end{tabular}

that calumenin may have an autocrine or a paracrine effect on the cells in its vicinity modulating cell cycle and organization of the actin cytoskeleton [45]. Additionally, calumenin and reticunocalbin were also differentially expressed in a study comparing early passage, senescent, and hTERT-transfected endothelial cells [46]. In this study, mRNA level of these proteins were upregulated in hTERT transfected cells compared to early passage subconfluent cells.

ORP150, GRP78, calreticulin, PDIs, ERp44, ERp46, FKBP9 are implicated in essential ER functions and $\mathrm{Ca}^{2+}$ homeostasis [47]. Interestingly, gene knockout experiments have proven that ER chaperon function is required for early mammalian development. Depletion of GRP78 leads to lethality in 3.5-day-old embryos (E3.5) due to failure of embryo peri-implantation [48]. This study suggests that physiological ER stress may exist in early development due to increased activity of cell proliferation and protein secretion. Calreticulin deficiency is also lethal in mouse embryos at E14.5, resulting from a lesion in cardiac development [49]. Interestingly GRP78 and calreticulin are downregulated after birth in the healthy mature heart [50]. ER chaperones overexpression are also proposed to promote cancer and tumor immunity [47]. It is interesting to note that telomerase is generally active in early embryonic stage and in $90 \%$ of cancers like these chaperones.
Our results indicate that overexpression of ER chaperones is a consequence of telomerase reactivation. The fact that these proteins are selectively upregulated in hTERT WI38 cells compared to WI38 and WI38-HPV control cells demonstrates that hTERT induces an important modulation of the ER functions. The ER is one of the most important folding compartments within the cell, as well as an intracellular $\mathrm{Ca}^{2+}$ storage organelle and it contains a number of $\mathrm{Ca}^{2+}$ regulated molecular chaperones responsible for the proper folding of glycosylated as well as non-glycosylated proteins. ER is also capable, through $\mathrm{Ca}^{2+}$ homeostasis modulation, to determine cellular sensitivity to ER stress and apoptosis [51]. We propose that upregulations of ER chaperones in hTERT transfected cells are responsible of a protective cell effect essential for the proliferation of hTERT immortalized cells. This protective effect is probably mediated by upregulation of GRP78 and calreticulin chaperones. In addition, FKBP9 may play an important role in the control of the timing of this biological process due to the recent discovery of its molecular timer function [52]. We propose also that intracellular and potent intercellular anti-apoptotic signaling are mediated by proteins belonging to the CREC family in hTERT positive cells trough a $\mathrm{Ca}^{2+}$ signaling modulation. Such proteome modulation makes evidence that telomerase reactivation, in addition of elongating telomere, has several indirect effects that augment ER capacity of protein folding and degradation [53-55]. 


\section{Conclusion}

We show that the methodology reduces the complexity of the proteome analysis and highlights proteins implicated in other processes than telomere elongation. hTERT transfection enhances natural ER capacity and modulates $\mathrm{Ca}^{2+}$ cell signaling pathways potentially resulting in overprotection mechanisms against endogeneous and exogeneous disorder. This hypothesis is in accordance with the identified down-regulation of apoptotic effectors Galectin-1 and Annexin 5. Other effects like an enhanced DNA excision repair pathway have also been reported in cell with long telomere [56]. Altogether, these observations suggest that telomerase expression enhances natural cell repair mechanisms and stress resistance probably required for long term resistance of immortalized cells. Therefore, hTERT transfected cells cannot be only considered as an immortal equivalent to parental cells but also as cells which are over-resistant to stresses. The introduction of hTERT gene in WI38 cells modulates the chaperone hsp $90 \alpha$ expression which seems to be, by its central position in the protein association network (Figure 2), an important regulator of subsequent cell adaptation mechanism to immortalization. This finding increases the interest of current anti cancer studies based on hsp90 inhibition. In addition to these observations, orthogonal analysis of our results with several cancerous cells proteomic studies reveals that some of the current highlighted proteins such as hsp90 $\alpha$, GRP78 and calreticulin are also implicated in oncogenese and cell resistance [5355]. Finally the model "parental WI38/hTERT WI38/HPV WI38" characterization (Table 2, 3) is the prerequisite for any larger proteomics aiming to evaluate anti-telomerase drugs proteome alteration and thus therapeutics induced cell reactions.

\section{Methods \\ Cell culture and infection of WI38 cells}

hTERT WI38, HPV WI38 and parental WI38 cells (human embryonic lung fibroblasts) were grown in Eagle's minimal essential medium with Glutamax (Invitrogen), supplemented with $10 \%$ fetal calf serum and penicillinstreptomycin 1\% (Gibco).

Lentiviral supernatants containing hTERT or control HPV vector were a generous gift from Dr. Annelise BennaceurGriscelli (Institut Gustave Roussy, Villejuif, France). Briefly, WI 38 cells at $1.5 \times 10^{5}$ cells $/ \mathrm{mL}$ were infected at a multiplicity of infection equal to 50 in the presence of 4 $\mu \mathrm{g} / \mathrm{mL}$ Polybrene in complete culture medium. Enhanced green fluorescent protein-positive cells were sorted 5 days later by flow cytometry according to a high or low intensity of fluorescence. Populations that expressed a high intensity of fluorescence were seeded [57].

\section{Non denaturing subfractionation method}

The non denaturing method of extraction and fractionation is based on the method of Gorski and co-workers [58] and has been adapted for WI38 cells. A cytosolic fraction and a nuclear histone-depleted proteins fraction were obtained. We verified the presence or not of telomerase activity by Western blots and TRAP (telomeric repeat amplification protocol) assay on each fraction. Then, a 2D LC-MS/MS analysis was performed and allowed the identification of more than 100 proteins per fraction. The two fractions shared a few number of common structural proteins and the nuclear fraction was enriched in low abundant proteins such as transcription factors and telomeric proteins (results not shown). For each experiment, $25 \mathrm{~T}$ 175 flasks $90 \%$ confluent are rinsed three times with PBS, then collected, using a scraper in a cold room at $4{ }^{\circ} \mathrm{C}$. The collected cells are centrifuged 5 minutes at $400 \mathrm{~g}$ and recovered. $10 \mathrm{~mL}$ of buffer 1 (Hepes-KOH $10 \mathrm{mM}$, pH 7.6; $\mathrm{KCl} 10 \mathrm{mM}$; Spermine/HCl $0.15 \mathrm{mM}$; Spermidine 0.5 $\mathrm{mM}$; DTT $0.5 \mathrm{mM}$ ) (10 times a volume equivalent to the fresh weight) is added to the cell pellet, homogenized and incubated 10 minutes on ice. The tube is then centrifuged 5 minutes at $800 \mathrm{~g}$ and the cells are recovered. One volume equivalent to the fresh weight of buffer 1 is added. The solution is homogenized with 10 strokes with a motorized potter Elvehjem homogenizer (Teflon/glass) at $4000 \mathrm{rpm}$ and the disruption of the cell membrane is controlled by Trypan Blue staining of nuclei with an inverted phase contrast microscope. $10 \%$ in volume of buffer 2 (Hepes-KOH $10 \mathrm{mM}$, pH 7.6; KCl $1 \mathrm{M}$; Spermine/ $\mathrm{HCl}$ $0.15 \mathrm{mM}$; Spermidine $0.5 \mathrm{mM}$; DTT $0.5 \mathrm{mM}$ ) is added to restore isotonicity of the solution, the solution is homogenized with 10 strokes at $4000 \mathrm{rpm}$ and centrifuged 10 minutes at $1100 \mathrm{~g}$. The pellet which contains nuclei is recovered, the supernatant is collected and centrifuged 30 minutes at $24000 \mathrm{~g}$. The supernatant is recovered and corresponds to the cytosolic fraction. The pellet (which contains nuclei) is homogenized in buffer 4 (Hepes-KOH 10 mM, pH 7.6; KCl 100 mM; Spermine/HCl 0.15 mM; Spermidine $0.5 \mathrm{mM}$; DTT $0.5 \mathrm{mM}$ ) with 5 strokes at $800 \mathrm{rpm}$ and centrifuged 5 minutes at $1100 \mathrm{~g}$. This step is repeated 3 times. The cleaned nuclei are homogenized in $2.25 \mathrm{~mL}$ of buffer (Hepes-KOH 10 mM, pH 7.6; KCl 100 mM; DTT $0.5 \mathrm{mM}$ ) with 5 strokes at $800 \mathrm{rpm}$ and transferred to a 3 mL ultra-centrifuge tube. $250 \mu \mathrm{L}$ of ammonium (10\% V/ V) sulfate is gently added and slowly agitated for $30 \mathrm{~min}$ utes. Then, a centrifugation is done at $90000 \mathrm{~g}$ for $40 \mathrm{~min}$ utes at $4^{\circ} \mathrm{C}$. The supernatant which contains nuclear proteins is transferred to another tube. $0.3 \mathrm{~g} / \mathrm{mL}$ of ammonium sulfate are added to the solution and let under smooth agitation for 40 minutes. The solution is centrifuged at $90000 \mathrm{~g}$ for 30 minutes at $4{ }^{\circ} \mathrm{C}$. $1 \mathrm{~mL}$ of buffer 7 (Hepes-KOH pH 7.625 mM; KCl 150 mM; DTT $1 \mathrm{mM}$ ) is added to the supernatant after the centrifugation and shaken for 15 minutes. The solution is dialyzed over- 
night and 2 hours again in buffer 7. The solution is centrifuged at $24000 \mathrm{~g}$ for 5 minutes. The supernatant is collected and constitutes the nuclear fraction.

\section{CyDye Labeling and Two-Dimensional Differential In-Gel Electrophoresis (2D-DIGE)}

DIGE technology was used with at least triplicate experiment for each nuclear and cytosol subproteomes from WI38, hTERT-WI38 and HPV-WI38. The DIGE technology allows 3 different protein fluorescent labelling by the use of Cy dyes. Two different samples are labelled by $\mathrm{Cy} 3$ and Cy5, whereas a pool of all samples is labelled by Cy2. A total of 12 2D-DIGE gels were realised corresponding to 24 different samples applied. The Cy2 internal standard sample reduces inter-gel experimental variations resulting in statistically improved results. Protein samples $(12.5 \mu \mathrm{g}$ each at $5 \mathrm{mg} / \mathrm{mL}$ ) were labelled in $7 \mathrm{M}$ urea, $2 \mathrm{M}$ thiourea, $1.5 \%(\mathrm{w} / \mathrm{v})$ ASB-14, 1.5\% (w/v) CHAPS, $20 \mathrm{mM}$ TRIS-

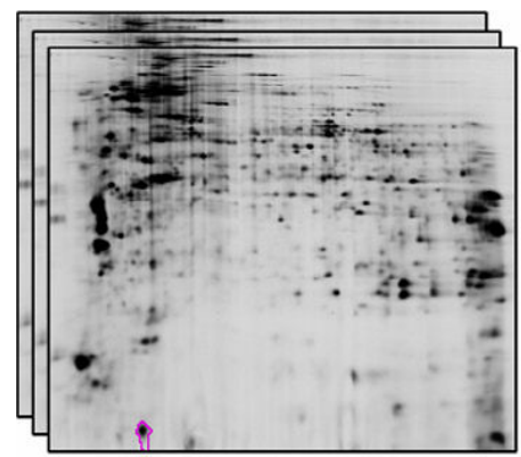

3 nuclear proteome WI 38 images and $3 \mathrm{D}$ view of the selected spot

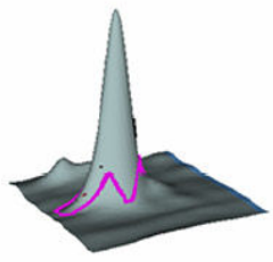

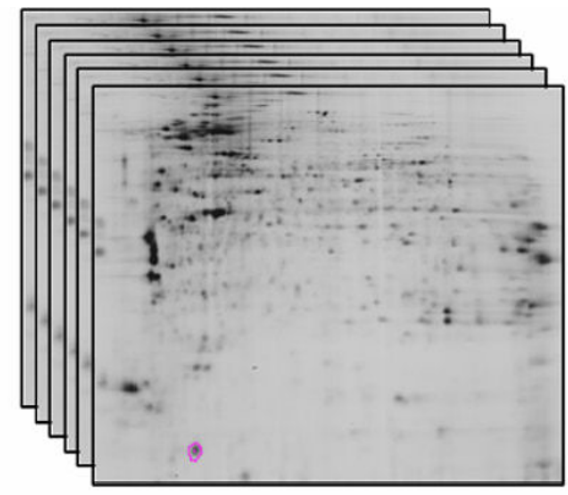

6 nuclear proteome hTERT-WI 38 images and $3 \mathrm{D}$ view of the selected spot

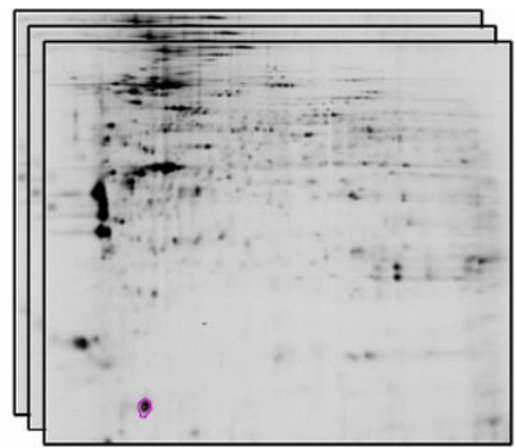

3 nuclear proteome HPV-WI38 images and $3 \mathrm{D}$ view of the selected spot
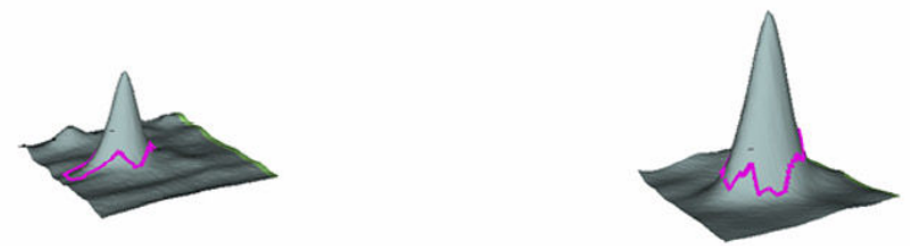

Graph of the standardized abundance of the selected spot in all gels

Galectin-1: P09382 (UniProtKB/Swiss-Prot entry)

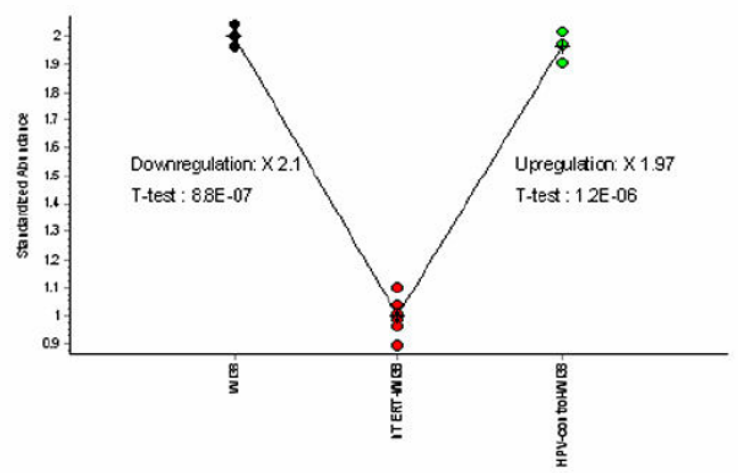

Mass spectrometry based identification

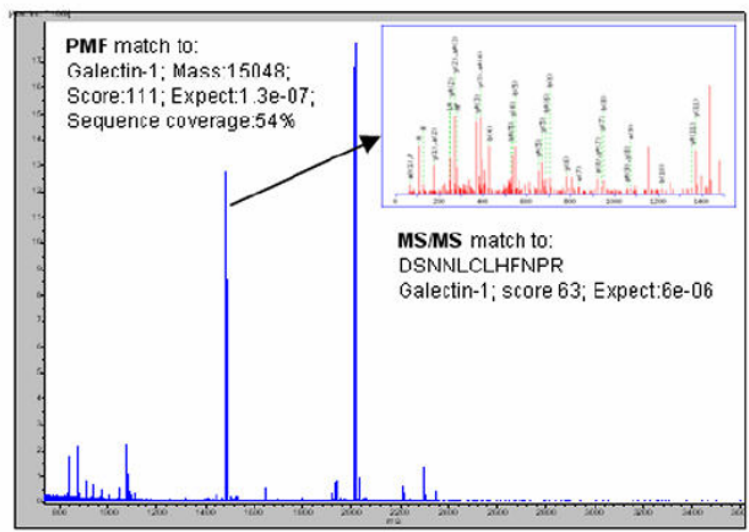

Figure 3

Experimental design. Figure 3 shows an example of the experimental design applied for differential 2D-DIGE analysis and mass spectrometry based identification. Nuclear sub-proteomes from WI38, hTERT WI38 and HPV-WI38. Each spot is selected from the standardized abundance, then excised and digested for MS/MS analysis. 
$\mathrm{HCl}, \mathrm{pH} 8.5$, according to the manufacturer procedure (Amersham Biosciences part of GE Healthcare). Samples were applied at least in triplicate with inversing Cy3/Cy5 labelling. An internal standard constituted by a mix of all samples was Cy2 labelled. Differentially labelled samples (12.5 $\mu \mathrm{g}$ of each Cy2-, Cy3-, and Cy5-labeled sample) were pooled and resolved isoelectrically on 24-cm IPG strips, pH 3-10, NL on a Protean IEF cell (Bio-Rad). After active rehydration for $9 \mathrm{~h}$ with the sample, the isoelectric focalisation is carried out up to 65000 Vh over night. IPG strips were seeded in reduction buffer for 15 minutes (DTT $130 \mathrm{mM}$, urea $6 \mathrm{M}$, Tris-HCl $0.373 \mathrm{M}$, pH 8.8, glycerol $20 \% \mathrm{v} / \mathrm{v}$, SDS $2 \% \mathrm{w} / \mathrm{v}$ ) followed by an alkylation (iodoacetamide $135 \mathrm{mM}$, urea $6 \mathrm{M}$, Tris- $\mathrm{HCl} \mathrm{pH} 8.8$ $0.373 \mathrm{M}$, glycerol $20 \% \mathrm{v} / \mathrm{v}$, SDS $2 \% \mathrm{w} / \mathrm{v}$ ) for additional 15 minutes. The second dimension electrophoresis was performed overnight at $20^{\circ} \mathrm{C}$ in an Ettan Dalt II system (G.E. Healthcare) at $1 \mathrm{~W}$ per gel. Each gel was finally scanned with the Typhoon 9400 scanner (G.E. Healthcare) at the wavelengths corresponding to each CyDye. Images were analyzed with the DeCyder software 6.5 (G.E. Healthcare) according to the manufacturer. Protein spots that showed a statistically significant Student's $t$-test $(p<0.05)$ for an increased or decreased in intensity superior at $30 \%$ were accepted as being differentially expressed. Only spots that had similar abundances in WI38 and WI38-HPV, and were differentially expressed in WI38-hTERT were selected for MS identification.

\section{Protein identification}

Spots of interest were automatically excised from the gel with the Ettan Spot Picker and submitted to tryptic digestion. The resulting peptides were extracted and rehydrated in $10 \mu \mathrm{L}$ of formic acid (1\%). One microliter of sample was deposited on an Ancorchip MALDI plate prespotted with HCCA matrix (Bruker-Daltonics). Samples were analyzed with an UltraFlex II MALDI-TOF-TOF (Bruker Daltonics) by MS fingerprint (spectra acquisition mass range:70-4000 $\mathrm{m} / \mathrm{z}$ ). Peaks with the highest intensities obtained in TOF-MS mode were subsequently analyzed by LIFT MS/MS for confirmation (mass range 40-4000). Protein identifications were carried out using the Biotools software (version: 3.0, build 2.9, Bruker Daltonics), the Mascot search engine (Version: 2.1.0) and SwissProt database (Sprot 50.8). All spots discussed here had a score corresponding to a p-value $<0.001$ (where $\mathrm{P}$ is the probability that the observed match is a random event). Identification with a p-value between 0.001 and 0.05 were all manually confirmed. Figure 3 shows an example of the general procedure applied for differential 2D analysis and mass spectrometry based identification.

\section{Competing interests}

The authors declare that they have no competing interests.

\section{Authors' contributions}

GDM, EDP, MC DPG, JFR, VG designed the study and interpreted part of the results. GDM performed most of the experiments, analyzed most of the results and drafted the manuscript. FR performed part of bioinformatics setup for mass spectrometry based identification. NS, MF and WA performed part of sample preparation and 2D DIGE experiments. All authors read and approved the final manuscript.

\section{Acknowledgements}

This work was supported by the FRS-FNRS (FRFC project 2.4.623.05). VG is a Research Associate and FR is a post doctoral fellow of the FNRS. NS and MF benefited from a FRIA PhD fellowship.

\section{References}

I. Bodnar AG, Ouellette M, Frolkis M, Holt SE, Chiu CP, Morin GB, Harley CB, Shay JW, Lichtsteiner S, WE Wright: Extension of life-span by introduction of telomerase into normal human cells. Science 1998, 279:349-52.

2. Jiang XR, Jimenez G, Chang E, Frolkis M, Kusler B, Sage M, Beeche M, Bodnar AG, Wahl GM, Tlsty TD, Chiu CP: Telomerase expression in human somatic cells does not induce changes associated with a transformed phenotype. Nat Genet 1999, 2 I: I I I-4.

3. Morales CP, Holt SE, Ouellette M, Kaur KJ, Yan Y, Wilson KS, White MA, Wright WE, Shay JW: Absence of cancer-associated changes in human fibroblasts immortalized with telomerase. Nat Genet 1999, 21 : I I5-8.

4. Kogan I, Goldfinger N, Milyavsky M, Cohen M, Shats I, Dobler G, Klocker H, Wasylyk B, Voller M, Aalders T, Schalken JA, Oren M, Rotter V: hTERT-immortalized prostate epithelial and stromal-derived cells: an authentic in vitro model for differentiation and carcinogenesis. Cancer Res 2006, 66:353I-40.

5. Huang Q, Chen M, Liang S, Acha V, Liu D, Yuan F, Hawks CL, Hornsby P): Improving cell therapy - experiments using transplanted telomerase-immortalized cells in immunodeficient mice. Mech Ageing Dev 2007, I 28:25-30.

6. Armstrong L, Saretzki G, Peters H, Wappler I, Evans J, Hole N, Zglinicki von T, Lako M: Overexpression of telomerase confers growth advantage, stress resistance, and enhanced differentiation of ESCs toward the hematopoietic lineage. Stem Cells 2005, 23:516-29.

7. Gonzalez-Suarez E, Samper E, Ramirez A, Flores JM, Martin-Caballero J, Jorcano JL, Blasco MA: Increased epidermal tumors and increased skin wound healing in transgenic mice overexpressing the catalytic subunit of telomerase, MTERT, in basal keratinocytes. Embo J 200I, 20:2619-30.

8. Serakinci N, Guldberg P, Burns JS, Abdallah B, Schrodder H, Jensen T, Kassem M: Adult human mesenchymal stem cell as a target for neoplastic transformation. Oncogene 2004, 23:5095-8.

9. Bates SE, Zhou NY, Federico LE, Xia L, TR O'Connor: Repair of cyclobutane pyrimidine dimers or dimethylsulfate damage in DNA is identical in normal or telomerase-immortalized human skin fibroblasts. Nucleic Acids Res 2005, 33:2475-85.

10. Gorbunova V, Seluanov A, Pereira-Smith OM: Expression of human telomerase (hTERT) does not prevent stressinduced senescence in normal human fibroblasts but protects the cells from stress-induced apoptosis and necrosis. J Biol Chem 2002, 277:38540-9.

II. Meerson A, Milyavsky M, Rotter V: p53 mediates density-dependent growth arrest. FEBS Lett 2004, 559:152-8.

12. Search Tool for the Retrieval of Interacting Genes/Proteins.

13. Maloney A, Workman P: HSP90 as a new therapeutic target for cancer therapy: the story unfolds. Expert Opin Biol Ther 2002, 2:3-24.

14. Keppler BR, Grady AT, Jarstfer MB: The biochemical role of the heat shock protein 90 chaperone complex in establishing human telomerase activity. J Biol Chem 2006, 28 I: 19840-8. 
15. Toogun OA, Dezwaan DC, Freeman BC: The hsp90 molecular chaperone modulates multiple telomerase activities. Mol Cell Biol 2008, 28:457-67.

16. Maloney A, Clarke PA, Naaby-Hansen S, Stein R, Koopman JO, Akpan A, Yang A, Zvelebil M, Cramer R, Stimson L, Aherne W, Banerji U, Judson I, Sharp S, Powers M, deBilly E, Salmons J, Walton M, Burlingame $A$, Waterfield $M$, Workman P: Gene and protein expression profiling of human ovarian cancer cells treated with the heat shock protein 90 inhibitor 17-allylamino-I7-demethoxygeldanamycin. Cancer Res 2007, 67:3239-53.

17. Sharp SY, Boxall K, Rowlands M, Prodromou C, Roe SM, Maloney A, Powers M, Clarke PA, Box G, Sanderson S, Patterson L, Matthews TP, Cheung KM, Ball K, Hayes A, Raynaud F, Marais R, Pearl L, Eccles S, Aherne W, McDonald E, Workman P: In vitro biological characterization of a novel, synthetic diaryl pyrazole resorcinol class of heat shock protein 90 inhibitors. Cancer Res 2007, 67:2206-16.

18. Powers MV, Workman P: Targeting of multiple signalling pathways by heat shock protein $\mathbf{9 0}$ molecular chaperone inhibitors. Endocr Relat Cancer 2006, I 3(SuppI I):SI25-35

19. Powers MV, Workman P: Inhibitors of the heat shock response: biology and pharmacology. FEBS Lett 2007, 58 I:3758-69.

20. Hadden MK, Galam L, Gestwicki JE, Matts RL, Blagg BS: Derrubone, an Inhibitor of the Hsp90 Protein Folding Machinery. J Nat Prod 2007.

21. Rodina A, Vilenchik M, Moulick K, Aguirre J, Kim J, Chiang A, Litz J, Clement CC, Kang Y, She Y, Wu N, Felts S, Wipf P, Massague J, Jiang X, Brodsky JL, Krystal GW, Chiosis G: Selective compounds define Hsp90 as a major inhibitor of apoptosis in small-cell lung cancer. Nat Chem Biol 2007, 3:498-507.

22. Williams $C R$, Tabios R, Linehan WM, Neckers L: Intratumor injection of the Hsp90 inhibitor I 7AAG decreases tumor growth and induces apoptosis in a prostate cancer xenograft model. J Urol 2007, I 78: I528-32.

23. Hiyama E, Hiyama K, Nishiyama M, Reynolds CP, Shay JW, Yokoyama $\mathrm{T}$ : Differential gene expression profiles between neuroblastomas with high telomerase activity and low telomerase activity. J Pediatr Surg 2003, 38: I730-4.

24. Yang RY, Liu FT: Galectins in cell growth and apoptosis. Cell Mol Life Sci 2003, 60:267-76.

25. Fluck Zacarias MF, Rico MJ, Gervasoni SI, llarregui JM, Toscano MA, Rabinovich GA, Scharovsky OG: Low-dose cyclophosphamide modulates galectin-I expression and function in an experimental rat lymphoma model. Cancer Immunol Immunother 2007, 56:237-48.

26. Biron VA, Iglesias MM, Troncoso MF, Besio-Moreno M, Patrignani ZJ, Pignataro OP, Wolfenstein-Todel C: Galectin- I: biphasic growth regulation of Leydig tumor cells. Glycobiology 2006, 16:810-2I.

27. Rabinovich GA, Alonso CR, Sotomayor CE, Durand S, Bocco JL, Riera $C M$ : Molecular mechanisms implicated in galectin- $I$-induced apoptosis: activation of the AP-I transcription factor and downregulation of Bcl-2. Cell Death Differ 2000, 7:747-53.

28. Walzel H, Fahmi AA, Eldesouky MA, Abou-Eladab EF, Waitz G, Brock J, Tiedge $M$ : Effects of $\mathbf{N}$-glycan processing inhibitors on signaling events and induction of apoptosis in galectin-I-stimulated Jurkat T lymphocytes. Glycobiology 2006, I 6: | 262-7|.

29. Brodie C, Blumberg PM: Regulation of cell apoptosis by protein kinase c delta. Apoptosis 2003, 8:19-27.

30. Kheifets V, Bright R, Inagaki K, Schechtman D, D Mochly-Rosen: Protein kinase $C$ delta (deltaPKC)-annexin $V$ interaction: a required step in deltaPKC translocation and function. J Biol Chem 2006, 281:23218-26.

31. Hawkins TE, Das D, Young B, Moss SE: DT40 cells lacking the $\mathrm{Ca2+-binding} \mathrm{protein} \mathrm{annexin} 5$ are resistant to $\mathbf{C a 2 + -}$ dependent apoptosis. Proc Natl Acad Sci USA 2002, 99:8054-9.

32. Xi L, Chen G, Zhou J, Xu G, Wang S, Wu P, Zhu T, Zhang A, Yang W, Xu Q, Lu Y, Ma D: Inhibition of telomerase enhances apoptosis induced by sodium butyrate via mitochondrial pathway. Apoptosis 2006, I I:789-98.

33. Chakraborty S, Ghosh U, Bhattacharyya NP, Bhattacharya RK, Roy M Inhibition of telomerase activity and induction of apoptosis by curcumin in K-562 cells. Mutat Res 2006, 596:81-90.

34. Wirth T, Kuhnel F, Fleischmann-Mundt B, Woller N, Djojosubroto M, Rudolph KL, Manns M, Zender L, Kubicka S: Telomerase-dependent virotherapy overcomes resistance of hepatocellular carcinomas against chemotherapy and tumor necrosis factor- related apoptosis-inducing ligand by elimination of $\mathrm{Mcl}-\mathrm{I}$. Cancer Res 2005, 65:7393-402.

35. Schul W, Groenhout B, Koberna K, Takagaki Y, Jenny A, Manders EM, Raska I, Driel van R, Jong de L: The RNA 3' cleavage factors CstF $64 \mathrm{kDa}$ and CPSF $100 \mathrm{kDa}$ are concentrated in nuclear domains closely associated with coiled bodies and newly synthesized RNA. Embo J 1996, I 5:2883-92.

36. Zhu Y, Tomlinson RL, Lukowiak AA, Terns RM, Terns MP: Telomerase RNA accumulates in Cajal bodies in human cancer cells. Mol Biol Cell 2004, I 5:8I-90.

37. Cioce M, Lamond Al: Cajal bodies: a long history of discovery. Annu Rev Cell Dev Biol 2005, 2 I: I05-3I.

38. Theimer CA, Jady BE, Chim N, Richard P, Breece KE, Kiss T, Feigon J: Structural and functional characterization of human telomerase RNA processing and cajal body localization signals. Mol Cell 2007, 27:869-8I.

39. Bettinger BT, Gilbert DM, Amberg DC: Actin up in the nucleus. Nat Rev Mol Cell Biol 2004, 5:4 I0-5.

40. Honore $B$, Vorum H: The CREC family, a novel family of multiple EF-hand, low-affinity $\mathbf{C a}(2+)$-binding proteins localised to the secretory pathway of mammalian cells. FEBS Lett 2000 , 466: II-8.

4I. Kent J, Lee M, Schedl A, Boyle S, Fantes J, Powell M, Rushmere N Abbott C, Heyningen van V, Bickmore WA: The reticulocalbin gene maps to the WAGR region in human and to the Small eye Harwell deletion in mouse. Genomics 1997, 42:260-7.

42. Chen JJ, Reid CE, Band V, Androphy EJ: Interaction of papillomavirus E6 oncoproteins with a putative calcium-binding protein. Science 1995, 269:529-31.

43. Liu Z, Brattain MG, Appert H: Differential display of reticulocalbin in the highly invasive cell line, MDA-MB-435, versus the poorly invasive cell line, MCF-7. Biochem Biophys Res Commun 1997, 23 I:283-9.

44. Nimmrich I, Erdmann S, Melchers U, Finke U, Hentsch S, Moyer MP Hoffmann I, Muller O: Seven genes that are differentially transcribed in colorectal tumor cell lines. Cancer Lett 2000, 1 60:37-43.

45. Ostergaard M, Hansen GA, Vorum H, Honore B: Proteomic profiling of fibroblasts reveals a modulating effect of extracellular calumenin on the organization of the actin cytoskeleton. Proteomics 2006, 6:3509-19.

46. Chang MW, Grillari J, Mayrhofer C, Fortschegger K, Allmaier G, Marzban G, Katinger $H$, Voglauer R: Comparison of early passage, senescent and hTERT immortalized endothelial cells. Exp Cell Res 2005, 309:121-36.

47. Ni M, Lee AS: ER chaperones in mammalian development and human diseases. FEBS Lett 2007, 58I:364I-5I.

48. Luo $S$, Mao $C$, Lee $B$, Lee AS: GRP78/BiP is required for cell proliferation and protecting the inner cell mass from apoptosis during early mouse embryonic development. Mol Cell Biol 2006, 26:5688-97.

49. Mesaeli N, Nakamura K, Zvaritch E, Dickie P, Dziak E, Krause KH, Opas M, MacLennan DH, Michalak M: Calreticulin is essential for cardiac development. J Cell Biol I999, I44:857-68.

50. Mao C, Tai WC, Bai Y, Poizat C, Lee AS: In vivo regulation of Grp78/BiP transcription in the embryonic heart: role of the endoplasmic reticulum stress response element and GATA4. J Biol Chem 2006, $281: 8877-87$.

5I. Groenendyk J, Michalak M: Endoplasmic reticulum quality control and apoptosis. Acta Biochim Pol 2005, 52:381-95.

52. Lu KP, Finn G, Lee TH, Nicholson LK: Prolyl cis-trans isomerization as a molecular timer. Nature Chemical Biology 2007, 3:619-629.

53. Castagna A, Antonioli P, Astner H, Hamdan M, Righetti SC, Perego P, Zunino F, Righetti PG: A proteomic approach to cisplatin resistance in the cervix squamous cell carcinoma cell line A43I. Proteomics 2004, 4:3246-67.

54. Luk JM, Lam CT, Siu AF, Lam BY, Ng IO, Hu MY, Che CM, Fan ST: Proteomic profiling of hepatocellular carcinoma in Chinese cohort reveals heat-shock proteins (Hsp27, Hsp70, GRP78) up-regulation and their associated prognostic values. Proteomics 2006, 6: 1049-57.

55. Hayashi E, Kuramitsu Y, Okada F, Fujimoto M, Zhang X, Kobayashi M, lizuka N, Ueyama Y, Nakamura K: Proteomic profiling for cancer progression: Differential display analysis for the expression 
of intracellular proteins between regressive and progressive cancer cell lines. Proteomics 2005, 5:1024-32.

56. Yu LR, Chan KC, Tahara H, Lucas DA, Chatterjee K, Issaq HJ, Veenstra TD: Quantitative proteomic analysis of human breast epithelial cells with differential telomere length. Biochem Biophys Res Commun 2007, 356:942-7.

57. Gomez D, Aouali N, Londono-Vallejo A, Lacroix L, Megnin-Chanet F, Lemarteleur T, Douarre C, K Shin-ya, Mailliet P, Trentesaux C, Morjani H, Mergny JL, Riou JF: Resistance to the short term antiproliferative activity of the G-quadruplex ligand 12459 is associated with telomerase overexpression and telomere capping alteration. I Biol Chem 2003, 278:50554-62.

58. Gorski K, Carneiro M, Schibler U: Tissue-specific in vitro transcription from the mouse albumin promoter. Cell 1986, 47:767-76.

59. Reddy RK, Lu J, Lee AS: The endoplasmic reticulum chaperone glycoprotein GRP94 with $\mathrm{Ca}(2+)$-binding and antiapoptotic properties is a novel proteolytic target of calpain during etoposide-induced apoptosis. J Biol Chem 1999, 274:28476-83.

60. Tamatani M, Matsuyama T, Yamaguchi A, Mitsuda N, Tsukamoto $Y$, Taniguchi M, Che YH, Ozawa K, Hori O, Nishimura H, Yamashita A, Okabe M, Yanagi H, Stern DM, Ogawa S, Tohyama M: ORPI 50 protects against hypoxia/ischemia-induced neuronal death. Nat Med 200I, 7:317-23.

61. Anelli T, Alessio M, Mezghrani A, Simmen T, Talamo F, Bachi A, Sitia $R$ : ERp44, a novel endoplasmic reticulum folding assistant of the thioredoxin family. Embo J 2002, $21: 835-44$.

62. Sullivan DC, Huminiecki L, Moore JW, Boyle JJ, Poulsom R, Creamer D, Barker J, Bicknell R: EndoPDI, a novel protein-disulfide isomerase-like protein that is preferentially expressed in endothelial cells acts as a stress survival factor. J Biol Chem 2003, 278:47079-88.

63. Tomsig JL, Creutz CE: Biochemical characterization of copine: a ubiquitous $\mathrm{Ca2+-dependent,} \mathrm{phospholipid-binding} \mathrm{protein.}$ Biochemistry 2000, 39:16163-75.

64. Caudell EG, Caudell JJ, Tang CH, Yu TK, Frederick MJ, Grimm EA: Characterization of human copine III as a phosphoprotein with associated kinase activity. Biochemistry 2000, 39:13034-43.

65. Knoblach B, Keller BO, Groenendyk J, Aldred S, Zheng J, Lemire BD, Li L, Michalak M: ERpI 9 and ERp46, new members of the thioredoxin family of endoplasmic reticulum proteins. Mol Cell Proteomics 2003, 2: I 104-19.

66. Ma Y, Hendershot LM: ER chaperone functions during normal and stress conditions. J Chem Neuroanat 2004, 28:5 I-65.

67. Takahashi Y, Takahashi S, Shiga Y, Yoshimi T, Miura T: Hypoxic induction of prolyl 4-hydroxylase alpha (I) in cultured cells. $J$ Biol Chem 2000, 275: 14139-46.

68. Ellgaard L, Ruddock LW: The human protein disulphide isomerase family: substrate interactions and functional properties. EMBO Rep 2005, 6:28-32.

69. Tu BP, Weissman JS: The FAD- and O(2)-dependent reaction cycle of Erol-mediated oxidative protein folding in the endoplasmic reticulum. Mol Cell 2002, 10:983-94.

70. Itoh T, Suzuki S, Suzuki A, Nakamura F, Naka M, Tanaka T: Effects of exogenously applied calponin on $\mathrm{Ca}(2+)$-regulated force in skinned smooth muscle of the rabbit mesenteric artery. Pflugers Arch 1994, 427:30I-8.

7I. Tang J, Hu G, Hanai J, Yadlapalli G, Lin Y, Zhang B, Galloway J, Bahary N, Sinha S, Thisse B, Thisse C, Jin JP, Zon LI, Sukhatme VP: A critical role for calponin 2 in vascular development. J Biol Chem 2006, 28I:6664-72.

72. Mizuno H, Khurts S, Seki T, Hirota Y, Kaneko S, Murakami S: Human telomerase exists in two distinct active complexes in vivo. J Biochem (Tokyo) 2007, I 4 I(5):64I-52.
Publish with Bio Med Central and every scientist can read your work free of charge

"BioMed Central will be the most significant development for disseminating the results of biomedical research in our lifetime. "

Sir Paul Nurse, Cancer Research UK

Your research papers will be:

- available free of charge to the entire biomedical community

- peer reviewed and published immediately upon acceptance

- cited in PubMed and archived on PubMed Central

- yours - you keep the copyright

Submit your manuscript here:

http://www.biomedcentral.com/info/publishing_adv.asp
BioMedcentral 